\title{
Growth responses and yield of cauliflower (Brassica oleracea var. botrytis L.) to the delayed transplanting and drought stress
}

\author{
Kartika $^{1,2}$, Lya Nailatul Fadilah ${ }^{1}$, and Benyamin Lakitan ${ }^{1,3 *}$ \\ ${ }^{1}$ College of Agriculture, Universitas Sriwijaya. Inderalaya 30662, Indonesia \\ ${ }^{2}$ Research Center for Biology, Indonesian Institute of Science (LIPI), Cibinong 16911, Indonesia \\ ${ }^{3}$ Research Center for Sub-optimal Lands (PUR-PLSO), Universitas Sriwijaya, Palembang 30139, \\ Indonesia
}

\begin{abstract}
Environmental condition is the main constrain of plant cultivation in riparian wetland. Transplanting time is frequently delayed due to flooding and the cultivated plants often experience drought stress during their generative stage due to insufficient water availability. The objective of this study was to evaluate the effect of delayed transplanting and drought stress on the growth and yield of cauliflower (Brassica oleracea Var. botrytis L.). The study was arranged based on the Factorial Randomized Block Design consisted of two factors, i.e., transplanting time and drought stress. The results showed that extended delay of transplanting for more than 25 days after sowing inhibited the plant growth, i.e., leaf number, canopy area, harvesting time, leaf weight, curd weight, curd volume, curd diameter, fresh and dry weight of roots, and root length. Halted water supply for 5 days during curd development resulted in a devastating drought stress since soil moisture dropped to $8 \%$. The drought stress significantly increased the root length, but this increase was unable to avoid yield reduction. It is suggested that transplanting time of cauliflower at riparian wetland should be carried out prior to 25 days after sowing.
\end{abstract}

\section{Introduction}

Cauliflower (Brassica oleracea var. botrytis L.) which contains high fiber, potassium, carotene, and vitamin C is commonly consumed vegetable in Indonesia [1]. In 2017, the production of cauliflower in Indonesia was 152.869 tons which 124 tons from South Sumatra. The production of cauliflower in South Sumatra increased by the time. However, the production area has decreased from 36 ha in 2017 to 27 ha in 2018 [2]. The cauliflower cultivation in South Sumatra is limited in the highlands area. The most suitable altitude for cauliflower cultivation was in range of 1000-3000 m above sea level [3]. However, several varieties had been developed to be adaptive in lowlands.

Riparian wetlands in South Sumatra cover about 2.98 million ha and only about 298.189 ha has been utilized for agricultural production [4]. Since large acreage of wetland is still underutilized, there is high opportunity to increase food and vegetable crop production in this

* Corresponding author: blakitan60@unsri.ac.id 
sub-optimal land. Riparian wetland is potential for developing cauliflower using appropriate cultivation techniques. Cauliflower can be cultivated simultaneously with rice. Cauliflower seedling can be cultivated at the end of flooding period and before the beginning of drought period. However, the environment condition in riparian wetland needs to be considered. The subsiding of floodwater to a level amenable for transplanting is highly unpredictable and uncontrollable [4]. This condition might cause the delay of seedling transplanting time. Optimum planting time is one of the important factors for producing maximum yield and benefit [5]. Optimum seedlings age of Brassica napus produce higher yield because of their strong growth [6] and more tolerant to disease than younger plants [7].

In riparian wetland in South Sumatra, optimum land condition for vegetable cultivation is less than three months. The best time for vegetable cultivation in lowland riparian is after rice transplanting or at the end of flooding period which usually from May until July. This condition might lead the cauliflower to experience drought stress during generative stage. Kartika et al [8] reported that farmers in riparian wetland only cultivate rice as main crop once annually due to drought condition during dry season which usually occur during plant generative growth. Limited water availability induce stomatal closure, reduce leaf water potential, a loss in turgor, and/or cell shrinkage which result in reduction of plant growth and development [9-11]. Water deficit during juvenility and curd induction reduced cauliflower's growth and marketable yield [11]. However, drought-resistant plants can regulate biophysico-chemical events to tolerate water deficit stress [13,14]. Therefore, this study was conducted to evaluate the growth responds of cauliflower to the delay of transplanting and drought stress condition.

\section{Materials and methods}

\subsection{Experimental site and plant material}

The study was carried out at an outdoor research facility in tropical lowland climate $\left(104^{\circ}\right.$ 46' 44' ' E; 3 $01^{\prime}$ ' 35' ' S), Palembang, South Sumatra, Indonesia. The altitude is less than 15 $\mathrm{m}$ above sea level. The study was conducted from May to September in 2020.

\subsection{Experimental design and cultivation management}

The plant material used was PM 126 F1 (lowland variety). Prior to sowing, seeds were soaked in tap water mixed with fungicide for 60 minutes to avoid plant disease during seedling stage. The seeds sowed in seedling tray filled with a mix of soil and manure $(1: 1 \mathrm{v} / \mathrm{v})$. The seedling then transplanted to pots based on treatments. The pots dimension was $26 \mathrm{~cm}$ in height and diameter of $22 \mathrm{~cm}$ (bottom) and $30 \mathrm{~cm}$ (top). The pots filled with $8 \mathrm{~kg}$ mixed of soil and manure $(3: 1 \mathrm{v} / \mathrm{v})$. Pots had 4 holes for direct outflow of excess water.

This study laid on a randomized block factorial design with 3 replications. The first factor was seedlings transplanting time, i.e., 25 days after sowing $\left(T_{1}\right)$, 32 days after sowing $\left(T_{2}\right)$, and 39 days after sowing $\left(\mathrm{T}_{3}\right)$. The second factor was drought stress conditions, including: control $\left(D_{0}\right)$, 76-81 days after sowing $\left(D_{1}\right)$, and 89-94 days after sowing $\left(D_{2}\right) . D_{1}$ and $D_{2}$ indicated curd initiation and curd development stage, respectively.

Each plant was fertilized with $5 \mathrm{~g}$ NPK (16:16:16) twice at 54 DAS and 75 DAS. All plants were well-watered except during drought stress treatment. Prior to drought stress treatment, plants were moved to plastic house to avoid raining. Each pot was supplied with sufficient water to reach field capacity. During drought stress, watery stopped for 5 days continuously. Control plants $\left(\mathrm{D}_{0}\right)$ were well-watered every day. 


\subsection{Observed variables and statistical analysis}

Plant growth was observed weekly from 40 days after sowing (DAS) until harvest. The variables observed included the average number of leaves, leaf canopy area $\left(\mathrm{cm}^{2}\right)$, SPAD value, leaf fresh weight $(\mathrm{g})$, stem fresh weight $(\mathrm{g})$, stem dry weight $(\mathrm{g})$, root length $(\mathrm{cm})$, root fresh weight (g), root dry weight (g), harvesting time (DAS), weight of curd (g), curd diameter $(\mathrm{cm})$, and curd volume $(\mathrm{ml})$. Data were subjected to the statistical analysis software (SAS 9.0 for Windows). Significant differences between drought and control conditions of each variable were analyzed by the Student's t-test in $\mathrm{P}<0.05$ was considered to indicate statistical significance.

\section{Results}

Leaf related variables were observed to evaluate the effect of the delay transplanting age to cauliflower vegetative growth. The delay of transplanting time decreased the number of leaves (Fig 1.A). Early transplanting time at 25 DAS resulted the highest number of leaves continuously from 47 DAS until 75 DAS. The lowest number of leaves showed when seedling transplanted at 39 DAS. Similar pattern appeared in plant canopy area. The delay of transplanting significantly reduced plant canopy area (Fig 1.B). Despite, there were not significantly different SPAD value of those transplanted in 25 DAS and 32 DAS, but reduction showed in plants transplanted at 39 DAS (Table 1). Regardless transplanting age, the number of leaves and canopy area were increasing gradually but not SPAD value. The average SPAD value of cauliflower was in range of 37.42-46.48.

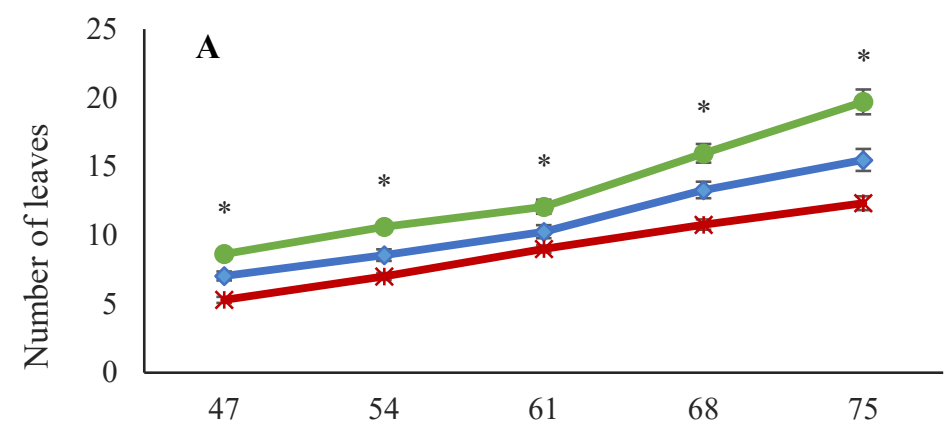




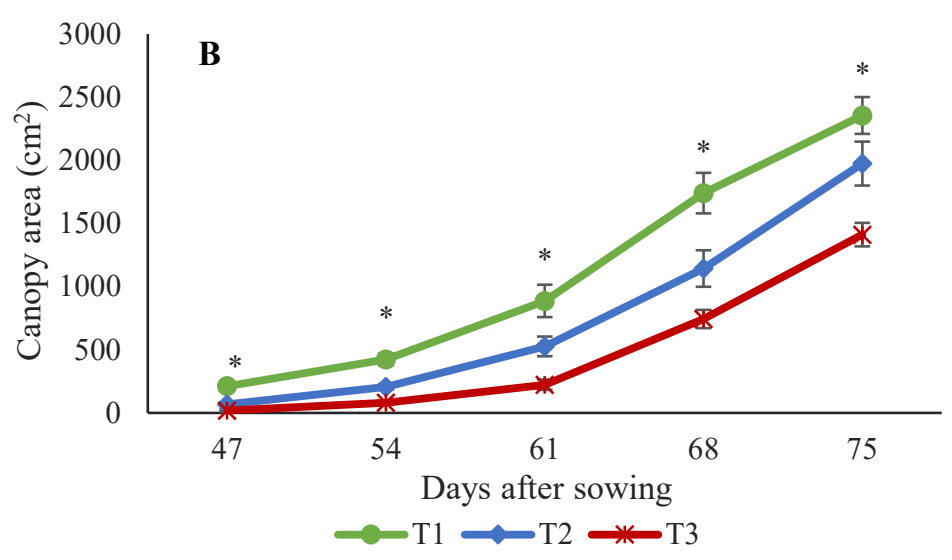

Fig. 1. The effect of transplanting time on number of leaves (A) and canopy area (B). $\mathrm{T} 1=$ transplanted at $25 \mathrm{DAS} ; \mathrm{T} 2$ transplanted at $32 \mathrm{DAS}$; T3 transplanted at 39 DAS.

Table 1. The effect of transplanting time on SPAD value of cauliflower

\begin{tabular}{|c|c|c|c|c|c|c|c|c|}
\hline \multirow{2}{*}{$\begin{array}{c}\text { Transplanting } \\
\text { time }\end{array}$} & \multicolumn{8}{|c|}{ Days after sowing (DAS) } \\
\hline & 54 & 58 & 61 & & 65 & 68 & 72 & \\
\hline $\mathrm{T}_{1}(25 \mathrm{DAS})$ & $42,49 \mathrm{a}^{\mathrm{z}}$ & $42,94 \mathrm{a}$ & 43,76 & $\mathrm{a}$ & 46,48 a & 44,84 a & 43,79 & a \\
\hline $\mathrm{T}_{2}(32 \mathrm{DAS})$ & $41,00 \mathrm{a}$ & 41,41 a & 42,11 & $a b$ & $45,10 \mathrm{ab}$ & 43,48 a & 41,57 & $\mathrm{a}$ \\
\hline $\mathrm{T}_{3}(39 \mathrm{DAS})$ & $37,42 \mathrm{~b}$ & $38,86 \mathrm{~b}$ & 40,03 & $\mathrm{~b}$ & $42,74 \mathrm{~b}$ & $40,71 \quad b$ & 41,36 & $\mathrm{a}$ \\
\hline BNT.05 & 2,23 & 1,85 & 2,65 & & 2,43 & 2,10 & 2,47 & \\
\hline
\end{tabular}

${ }^{\mathrm{z}}$ Mean values within a column followed by the same letters are not significantly different at $\mathrm{p}<0.05$.

Soil moisture of the plants imposed to drought stress significantly lower than control. Soil moisture decreased faster when drought stress occurred during curd initiation stage $\left(D_{1}\right)$. Soil moisture was significantly decreased from 3 days after drought stress, except for those plants transplanted at 39 DAS. The reduction of soil moisture was slower when plant imposed to drought stress during curd development stage (Fig. 2).
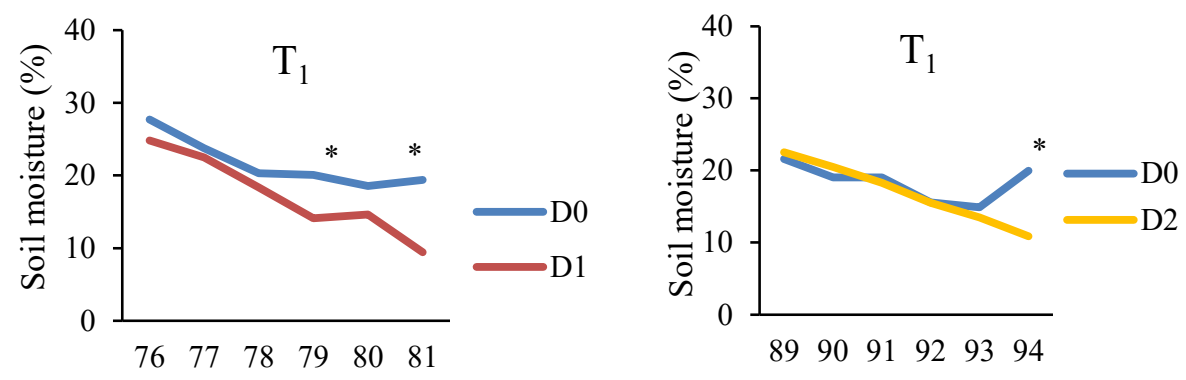

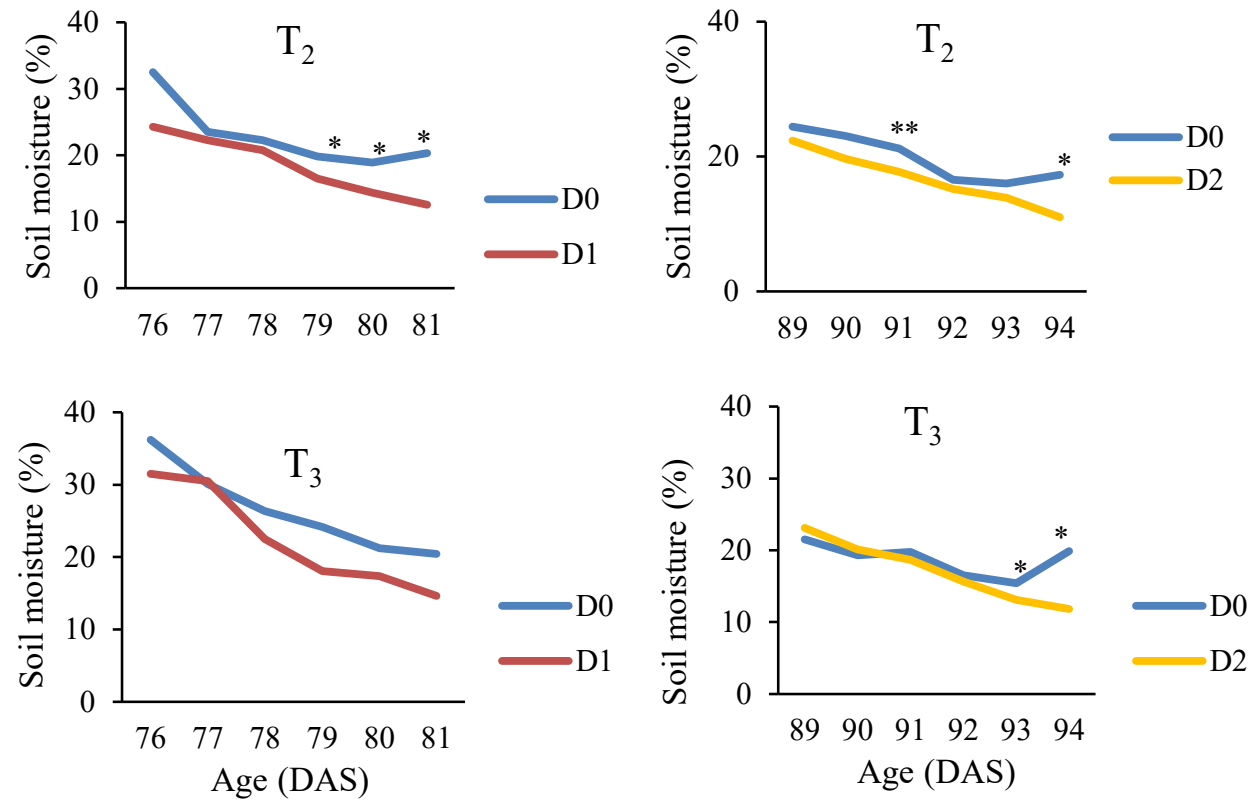

Fig. 2. Soil moisture of cauliflower transplanted at different time under drought stress condition. $\mathrm{T} 1=$ transplanted at $25 \mathrm{DAS}$; T2 transplanted at $32 \mathrm{DAS}$; T3 transplanted at $39 \mathrm{DAS}$. D0=control; $\mathrm{D} 1=$ drought stress at 76-81 DAS; D2=drought stress at 89-94 DAS. Means of control and drought plants of each genotype were compared by the Student's t-test $(* \mathrm{P}<0.05)$.

Transplanting time significantly affect above ground organs biomass, i.e., leaf and stem (Table 2). Transplanting time did not affect root biomass but significantly affect root length. Earlier transplanting time resulted longer root length. Drought stress during curd development stage significantly reduce leaf weight but increased root length. The interaction between delay transplanting time (32 DAS and 39 DAS) and drought stress during curd development stage showed lowest weight of leaves and stem.

Table 2. The effect of transplanting time, drought stress, and their interaction on plant biomass.

\begin{tabular}{|c|c|c|c|c|c|c|}
\hline Treatment & $\begin{array}{l}\text { Leaf weight } \\
\text { (g) }\end{array}$ & $\begin{array}{c}\text { Stem fresh } \\
\text { weight } \\
\text { (g) }\end{array}$ & $\begin{array}{l}\text { Stem dry } \\
\text { weight } \\
\text { (g) }\end{array}$ & $\begin{array}{l}\text { Root fresh } \\
\text { weight } \\
\text { (g) }\end{array}$ & $\begin{array}{l}\text { Root dry } \\
\text { weight } \\
\text { (g) }\end{array}$ & $\begin{array}{c}\text { Root } \\
\text { length } \\
\text { (g) }\end{array}$ \\
\hline \multicolumn{7}{|c|}{ Transplanting time } \\
\hline $\begin{array}{l}25 \text { DAS }\left(T_{1}\right) \\
32 \text { DAS }\left(T_{2}\right) \\
39 \text { DAS }\left(T_{3}\right) \\
\text { BNT.05 }\end{array}$ & $\begin{array}{c}195.22 \mathrm{a}^{\mathrm{z}} \\
170.56 \mathrm{ab}^{2} \\
145.50 \mathrm{~b} \\
27.55 \\
\end{array}$ & $\begin{array}{c}53.39 \mathrm{a} \\
42.00 \mathrm{~b} \\
43.18 \mathrm{~b} \\
6.81 \\
\end{array}$ & $\begin{array}{c}8.51 \mathrm{a} \\
7.07 \mathrm{~b} \\
7.65 \mathrm{ab} \\
0.87\end{array}$ & $\begin{array}{cc}93.57 & \mathrm{a} \\
78.54 & \mathrm{a} \\
80.01 & \mathrm{a} \\
19.48 & \\
\end{array}$ & $\begin{array}{c}22.14 \mathrm{a} \\
19.15 \mathrm{a} \\
17.70 \mathrm{a} \\
5.05 \\
\end{array}$ & $\begin{array}{c}40.84 \mathrm{a} \\
36.50 \mathrm{~b} \\
38.18 \mathrm{ab} \\
4.32 \\
\end{array}$ \\
\hline \multicolumn{7}{|c|}{ Drought stress } \\
\hline $\begin{array}{l}\text { Control }\left(\mathrm{D}_{0}\right) \\
\text { 76-81 DAS }\left(\mathrm{D}_{1}\right) \\
89-94 \text { DAS }\left(\mathrm{D}_{2}\right) \\
\text { BNT.05 }\end{array}$ & $\begin{array}{c}179.67 \quad \mathrm{a} \\
191.22 \mathrm{a} \\
140.39 \mathrm{~b} \\
27.55\end{array}$ & $\begin{array}{c}47.11 \mathrm{a} \\
49.14 \mathrm{a} \\
42.32 \mathrm{a} \\
6.81 \\
\end{array}$ & $\begin{array}{c}7.79 \mathrm{a} \\
7.86 \mathrm{a} \\
7.58 \mathrm{a} \\
0.87\end{array}$ & $\begin{array}{ll}82.68 & \mathrm{a} \\
81.87 & \mathrm{a} \\
87.57 & \mathrm{a} \\
19.48 & \\
\end{array}$ & $\begin{array}{c}18.77 \mathrm{a} \\
19.76 \mathrm{a} \\
20.45 \mathrm{a} \\
5.05\end{array}$ & $\begin{array}{c}36.23 \mathrm{~b} \\
35.70 \mathrm{~b} \\
43.59 \mathrm{a} \\
4.32\end{array}$ \\
\hline \multicolumn{7}{|c|}{ Interaction between transplanting time and drought stress } \\
\hline $\begin{array}{l}\mathrm{T}_{1} \mathrm{D}_{0} \\
\mathrm{~T}_{1} \mathrm{D}_{1} \\
\mathrm{~T}_{1} \mathrm{D}_{2} \\
\mathrm{~T}_{2} \mathrm{D}_{0} \\
\mathrm{~T}_{2} \mathrm{D}_{1}\end{array}$ & $\begin{array}{ll}200.00 & \mathrm{a} \\
239.17 & \mathrm{ab} \\
146.50 & \mathrm{~cd} \\
188.17 & \mathrm{bc} \\
187.00 & \mathrm{bc}\end{array}$ & $\begin{array}{ll}51.03 & \mathrm{ab} \\
58.22 & \mathrm{a} \\
50.93 & \mathrm{ab} \\
43.47 & \mathrm{bc} \\
45.30 & \mathrm{bc}\end{array}$ & $\begin{array}{ll}8.54 & \mathrm{a} \\
8.41 & \mathrm{a} \\
8.58 & \mathrm{a} \\
7.29 & \mathrm{ab} \\
7.27 & \mathrm{ab}\end{array}$ & $\begin{array}{cl}109.91 & \mathrm{a} \\
92.10 & \mathrm{ab} \\
78.72 & \mathrm{abc} \\
75.15 & \mathrm{bc} \\
84.86 & \mathrm{abc}\end{array}$ & $\begin{array}{l}24.40 \mathrm{a} \\
24.46 \mathrm{a} \\
17.55 \mathrm{ab} \\
17.50 \mathrm{ab} \\
19.97 \mathrm{ab}\end{array}$ & $\begin{array}{cc}39.5 & \mathrm{~b} \\
35.88 & \mathrm{~b} \\
47.15 & \mathrm{a} \\
36.5 & \mathrm{~b} \\
36.6 & \mathrm{~b}\end{array}$ \\
\hline
\end{tabular}




\begin{tabular}{|c|c|c|c|c|c|c|}
\hline $\mathrm{T}_{2} \mathrm{D}_{2}$ & $136.50 \mathrm{~d}$ & $37.22 \mathrm{c}$ & $6.67 \mathrm{~b}$ & 75.63 & $19.98 \mathrm{ab}$ & 36.4 \\
\hline $\mathrm{T}_{3} \mathrm{D}_{0}$ & 150.00 & $46.83 \mathrm{abc}$ & $7.55 \mathrm{ab}$ & 62.99 & $14.42 \mathrm{~b}$ & 32.7 \\
\hline $\mathrm{T}_{3} \mathrm{D}_{1}$ & 147.50 & $43.88 \mathrm{bc}$ & $7.91 \mathrm{ab}$ & 68.69 & $14.84 \mathrm{~b}$ & 34.61 \\
\hline $\mathrm{T}_{3} \mathrm{D}_{2}$ & $138.17 \mathrm{~d}$ & $38.82 \mathrm{c}$ & $7.49 \mathrm{ab}$ & $108.38 \mathrm{ab}$ & $23.84 \mathrm{a}$ & $47.23 \mathrm{a}$ \\
\hline BNT.05 & 47.72 & 11.80 & 1.51 & 33.75 & 8.76 & 7.49 \\
\hline
\end{tabular}

${ }^{\mathrm{z}}$ Mean values within a column followed by the same letters are not significantly different at $\mathrm{p}<0.05$.

The delay of transplanting time leads to the delay of harvesting time and lower yield (Table 3). Plants transplanted at 39 DAS were harvested 9 days later than those transplanted at 25 DAS. In this study, yield indicated by weight and diameter of curd. The highest weight and diameter of curd obtained by the plants transplanted at 25 DAS, followed by 32 DAS and 39 DAS. Harvesting time and yield were also affected by drought stress condition. Limited water availability during curd development stage delaying harvesting time and significantly reduced curd weight and diameter. The interaction between the delay of transplanting time at $32 \mathrm{DAS}$ and drought stress condition during curd development postponed 8 days of harvesting time and 14 days when transplanted ad 39 DAS. The highest reduction of curd weight and diameter showed in combination of the delay transplanting time at 39 DAS and drought stress during curd development. The volume of curd did not affect by transplanting time, drought stress, and interaction of both treatments. 
Table 3. The effect of transplanting time, drought stress, and their interaction on harvesting time and yield variables.

\begin{tabular}{|c|c|c|c|c|c|c|c|c|}
\hline \multirow[t]{2}{*}{ Treatment } & \multicolumn{2}{|c|}{$\begin{array}{l}\text { Harvesting time } \\
\text { (DAS) }\end{array}$} & \multicolumn{2}{|c|}{$\begin{array}{c}\text { Curd weight } \\
\text { (g) }\end{array}$} & \multicolumn{2}{|c|}{$\begin{array}{l}\text { Curd diameter } \\
(\mathrm{cm})\end{array}$} & \multicolumn{2}{|c|}{$\begin{array}{l}\text { Curd volume } \\
\left(\mathrm{cm}^{3}\right)\end{array}$} \\
\hline & & & \multicolumn{4}{|c|}{ Transplanting time } & & \\
\hline $25 \operatorname{DAS}\left(\mathrm{T}_{1}\right)$ & 101.22 & $c^{z}$ & 110.00 & $\mathrm{a}$ & 13.84 & $\mathrm{a}$ & 60.00 & $\mathrm{a}$ \\
\hline $32 \mathrm{DAS}\left(\mathrm{T}_{2}\right)$ & 104.44 & $\mathrm{~B}$ & 80.90 & $\mathrm{~b}$ & 12.31 & $\mathrm{ab}$ & 46.11 & a \\
\hline $39 \mathrm{DAS}\left(\mathrm{T}_{3}\right)$ & 110.27 & A & 80.05 & $\mathrm{~b}$ & 11.86 & $\mathrm{~b}$ & 54.11 & $\mathrm{a}$ \\
\hline BNT.05 & \multicolumn{2}{|c|}{3.09} & \multicolumn{2}{|c|}{17.43} & \multicolumn{2}{|c|}{1.98} & \multicolumn{2}{|c|}{25.16} \\
\hline \multicolumn{9}{|c|}{ Drought stress } \\
\hline Control $\left(\mathrm{D}_{0}\right)$ & 103.33 & B & 104.07 & a & 13.61 & $\mathrm{a}$ & 59.67 & $\mathrm{a}$ \\
\hline $76-81$ DAS $\left(\mathrm{D}_{1}\right)$ & 102.83 & B & 89.26 & $a b$ & 12.79 & $a b$ & 47.83 & $\mathrm{a}$ \\
\hline 89-94 DAS $\left(\mathrm{D}_{2}\right)$ & 109.77 & A & 77.93 & $\mathrm{~b}$ & 11.60 & $\mathrm{~b}$ & 52.83 & $\mathrm{a}$ \\
\hline $\mathrm{BNT}_{.05}$ & \multicolumn{2}{|c|}{3.09} & \multicolumn{2}{|c|}{17.43} & \multicolumn{2}{|c|}{1.98} & \multicolumn{2}{|c|}{25.16} \\
\hline \multicolumn{9}{|c|}{ Interaction between transplanting time and drought stress } \\
\hline $\mathrm{T}_{1} \mathrm{D}_{0}$ & 101.16 & Ed & 125.42 & $\mathrm{a}$ & 13.60 & $a b$ & 76.67 & $\mathrm{a}$ \\
\hline $\mathrm{T}_{1} \mathrm{D}_{1}$ & 98.00 & $\mathrm{E}$ & 106.66 & $a b$ & 14.45 & $\mathrm{a}$ & 39.50 & $\mathrm{a}$ \\
\hline $\mathrm{T}_{1} \mathrm{D}_{2}$ & 104.50 & Bcd & 98.90 & $a b c$ & 13.48 & $a b$ & 63.83 & a \\
\hline $\mathrm{T}_{2} \mathrm{D}_{0}$ & 102.00 & Cde & 97.43 & abcd & 14.36 & $\mathrm{a}$ & 50.67 & $\mathrm{a}$ \\
\hline $\mathrm{T}_{2} \mathrm{D}_{1}$ & 102.16 & Cde & 74.86 & cde & 11.46 & $a b$ & 52.67 & $\mathrm{a}$ \\
\hline $\mathrm{T}_{2} \mathrm{D}_{2}$ & 109.16 & B & 67.87 & de & 11.09 & $a b$ & 35.00 & $\mathrm{a}$ \\
\hline $\mathrm{T}_{3} \mathrm{D}_{0}$ & 106.83 & $\mathrm{Bc}$ & 89.37 & bcde & 12.88 & $a b$ & 51.67 & $\mathrm{a}$ \\
\hline$T_{3} D_{1}$ & 108.33 & B & 86.28 & bcde & 12.46 & $a b$ & 51.33 & $\mathrm{a}$ \\
\hline $\mathrm{T}_{3} \mathrm{D}_{2}$ & 115.66 & A & 67.05 & $\mathrm{e}$ & 10.23 & $\mathrm{~b}$ & 59.67 & $\mathrm{a}$ \\
\hline BNT.05 & \multicolumn{2}{|c|}{5.35} & \multicolumn{2}{|c|}{30.19} & \multicolumn{2}{|c|}{3.43} & \multicolumn{2}{|c|}{43.58} \\
\hline
\end{tabular}

\section{Discussion}

Younger seedlings could adapt to new environment faster than older seedlings promoting better growth and higher yield. The phyllochronic utilization followed by younger aged seedlings improve plant growth parameters [14]. Younger seedlings containing higher nitrogen and higher ability to faster resumption of phyllochron development rate [15]. The phyllochron is defined as the time interval between the appearances of successive leaf tips. Higher endosperm nutrient contents during $2^{\text {nd }}$ and $3^{\text {rd }}$ phyllochrons support the faster recovery of younger seedlings. Therefore, the delay of seedlings transplanting cause the plant taking a little longer time for recovery from the transplanting shock.

This study revealed that number of leaves and canopy area significantly lower due to the delay of transplanting since the seedling age was too old. This result was in accordance to Ko et al. [16] that younger seedling resulting higher number and size of leaves. Leaf regulates the interception of solar radiation and gaseous exchange promoting photosynthesis and other metabolic processes [17]. Fewer green leaves resulted in a weak photosynthetic system which leads to low shoot and root dry matter [6]. The results of this study showed that the delay of seedling transplanting time not only decreased plant biomass but also yield attributes, i.e., curd weight and diameter.

Cauliflower is classified as an intermediate susceptible to water stress vegetable crop [18]. Cauliflower requires high water due to its large weight of leaves [19]. Khan et al. [20] reported that cauliflower require 380 to $500 \mathrm{~mm}$ water with an interval of irrigation from 5 to 10 days and during the duration of growth $45 \%$ depletion in rhizosphere is allowable. Drought stress induce ABA synthesis which leads to stomatal closure and the activation of stress related genes [21]. Krzesiński et al. [19] reported that reducing soil water content until $20 \%$ of field capacity significantly decrease net photosynthesis, transpiration and stomatal 
conductance of cauliflower. This condition resulted lower assimilate production which affecting plant growth. In this study, the reduction of soil moisture was slower and not significant for the plants transplanted at 39 DAS. This condition might be due to the lower number of leaves and canopy area which resulted in the lower amount of water lost by transpiration.

This study revealed that drought stress during curd development significantly increased root length but decreased plant growth and biomass. The results of our study are consistent to Hossain et al. [22] that number of leaves of Brassica oleraceae decreased under drought stress condition while root length increased. Drought stress mostly reduces leaf growth and increases the allocation of assimilate into the root fraction [23]. That condition leading to increase of root length. However, drought stress elevates the concentration of solute in extracellular matrices and cytosol due to reduction of cell water potential and turgor [24]. This condition reduces cell enlargement followed by slowing down or stopping growth and reproductive failure. Thus, total dry mass significant reduced since drought stress occurred during plants generative stage.

This study showed that the lowland cauliflower variety can produce head (sometimes called curd) under limited water availability. However, the weight and diameter of the head were inferior. The results are similar to that of Khan et al. [20] who reported low application of water unable to obtain maximum curd diameter in cauliflower. Sufficient amount of soil water availability subsequently contributed in the formation of larger and comparatively broader curd [22].

\section{Conclusion}

Delayed transplanting negatively affects the growth and yield of cauliflower. Transplanting of seedling should not be conducted later than 25 days after sowing, otherwise plant unable to exhibited good performance on both vegetative and yield attributes. Furthermore, the delay of transplanting caused the plant taking a longer time to harvest. Lowland variety of cauliflower can be grown under limited water availability. However, severe drought will result in a lower curd weight and diameter.

Acknowledgement. This publication was funded by the Program Penelitian Unggulan Profesi, Universitas Sriwijaya, grant No. 0014/UN9/SK.LP2M.PT/2021.

\section{References}

1. M.E. Sofian, A.D. Susila. J. Trop. Crop Sci. 5, 1-5 (2018)

2. Badan Pusat Statistik. Statistik Tanaman Sayuran dan Buah-Buahan Semusim Indonesia. (2018)

3. D.B. Ajithkumar, V.P. Karthika, D.V.U.M. Rao, Crop weather relationships in Cauliflower (Brassica oleracea var. botrytis L.) in the Central zone of Kerala, (Kerala Agricultural University Press, Mannuthy, 2014)

4. B. Lakitan, B. Hadi, S. Herlinda, E. Siaga, L.I. Widuri, K. Kartika, L. Lindiana, Y. Yunindyawati, M. Meihana. NJAS - Wageningen J. Life Sci., 85, 10-20 (2018)

5. M. Rahman, M. Imran, M. Ikrum, M. Rahman, M. Rabbani. J. Environ. Sci. Nat. Resour. 9, 143-150 (2017)

6. Y. Ren, J. Zhu, N. Hussain, S. Ma, G. Ye, D. Zhang, S. Hua.Can. J. Plant Sci. 94, 14611469 (2014)

7. S.F. Hwang, H.U. Ahmed, S.E. Strelkov, B.D. Gossen, G.D. Turnbull, G. Peng, R. J. Howard. Can. J. Plant Sci. 91, 183-190 (2011) 
8. K. Kartika, J.I. Sakagami, B. Lakitan, S. Yabuta, A. Wijaya, S. Kadir, L.I. Widuri, E. Siaga, Y. Nakao. Rice Sci. 27, 67-74 (2020)

9. L.I. Widuri, B. Lakitan, J. Sakagami, S. Yabuta, K. Kartika, E. Siaga. Ann. Agric. Sci. 65, 149-158 (2020)

10. M. Latif, N.A. Akram, M. Ashraf. J. Hortic. Sci. Biotechnol. 91, 129-137 (2016)

11. A. Abdelkhalik, B. Pascual, I. Nájera, C. Baixauli, N. Pascual-Seva. Agronomy. 9, 732 (2019)

12. V. Parkash, S. Singh. Sustain. 12, 1-28 (2020)

13. S.A.R. Hammad, O.A. M. Ali. Ann. Agric. Sci. 59, 133-145 (2014)

14. A. Vishwakarma, J.K. Singh, A. Sen, J.S. Bohra, S. Singh. Indian J. Agric. Sci. 865, 679-685 (2016)

15. G. Ginigaddara, S. Ranamukhaarachchi. Recent Res. Sci. Technol. 3, 76-88 (2011)

16. K.M.M. Ko, Y. Hirai, O.B. Zamora, L.E. de Guzman. Am. J. Plant Sci. 8, 1-12 (2017)

17. J. Shrestha, M. Kandel, A. Chaudhary. J. Agric. Nat. Resour. 1, 43-50 (2018)

18. A.M. Seciu, A. Oancea, A. Gaspar, L. Moldovan, O. Craciunescu, L. Stefan, V. Petrus, F. Georgescu. Agric. Agric. Sci. Procedia. 10, 475-484 (2016)

19. W. Krzesiński, T. Spiżewski, A. Kałużewicz, B. Frąszczak, A. Zaworska, J. Lisiecka. Nauk. Przyr. Technol. 10, 1-10 (2017)

20. N. Khan, Z. Ullah, J. Ahmad, A. Khan, F. Nawaz, Sohail, N. Khan, Z. Ullah, J. Ahmad, A. Khan, F. Nawaz, R. Khan. Pure Appl. Biol. 7, 910-921 (2018)

21. H.Z. Rihan, M. Al-Issawi, M. Al-Shamari, M. Elmahrouk, M.P. Fuller. Acta Horticulturae. 43-52 (2015)

22. M. Hossain, M. Mohona. Int. J. Hortic. Sci. Technol. 5, 11-18 (2018)

23. H. Kage, M. Kochler, H. Stützel. Eur. J. Agron. 20, 379-394 (2004)

24. S.Y.S. Lisar, R. Motafakkerazad, I.M.M. Rahm. Water Stress. 1-14 (2012) 